\title{
Soil moisture and soybean physiology affected by drought in an integrated crop-livestock system
}

\author{
Amanda Posselt Martins ${ }^{(1)}$, Sérgio Ely Valadão Gigante de Andrade Costa(1), Ibanor Anghinoni ${ }^{(1)}$, \\ Taise Robinson Kunrath ${ }^{(1)}$, Diego Cecagno(1), José Miguel Reichert( ${ }^{(2)}$, Fabrício Balerini(1), \\ Lúcia Rebello Dillenburg( ${ }^{(1)}$ and Paulo César de Faccio Carvalho ${ }^{(1)}$
}

\begin{abstract}
(1) Universidade Federal do Rio Grande do Sul, Faculdade de Agronomia, Avenida Bento Gonçalves, no 7.712, CEP 91540-000 Porto Alegre, RS, Brazil. E-mail: amandaposselt@gmail.com, sergioelycosta2011@hotmail.com, ibanghi@ufrgs.br, taiserk@gmail.com, dcecagno@hotmail.com, balerinifabricio@gmail.com, lucia.dillenburg@ufrgs.br, paulocfc@ufrgs.br (2)Universidade Federal de Santa Maria, Centro de Ciências Rurais, Departamento de Solos, Avenida Roraima, no 1.000, Cidade Universitária, Camobi, CEP 97105-900 Santa Maria, RS, Brazil. E-mail: reichert@ufsm.br
\end{abstract}

\begin{abstract}
The objective of this work was to evaluate the impact of grazing intensities after 11 years of an integrated crop-livestock system, under no-tillage, on soil moisture and soybean physiological parameters during a summer season affected by drought. The experiment was established in 2001 on a Rhodic Hapludox. Treatments consisted in the succession of soybean (summer) and a mixed pasture of black oat + Italian ryegrass (winter), under different beef-cattle grazing intensities: intensive grazing, with $0.10-\mathrm{m}$ pasture height; moderate grazing, with 0.20-m pasture height; and no grazing. During the soybean cycle, in the 2011/2012 crop season, rainfall was $40 \%$ of the climatological normal. The soil moisture was within the limits of available water both under moderate grazing and no grazing, at $0.00-0.50-\mathrm{m}$ soil depth, but, under intensive grazing, it was below the permanent wilting point, especially up to the grazing height of $0.20 \mathrm{~m}$. Intensive grazing affected negatively the plant physiology parameters, reaching peaks of $-2.5 \mathrm{MPa}$ and $+6^{\circ} \mathrm{C}$ for leaf water potential and leaf-air temperature difference, respectively. Moderate grazing or the absence of grazing, during the winter season, results in similar physiological responses, contributing to soybean plant homeostasis.
\end{abstract}

Index terms: Glycine max, leaf temperature, leaf water potential, water availability.

\section{Umidade do solo e fisiologia da soja afetados por estiagem em sistema de integração lavoura-pecuária}

Resumo - O objetivo deste trabalho foi avaliar o impacto de intensidades de pastejo após 11 anos de um sistema de integração lavoura-pecuária, em plantio direto, na umidade do solo e em parâmetros fisiológicos da soja durante uma safra de verão afetada por seca. O experimento foi iniciado em 2001, em um Latossolo Vermelho. Os tratamentos consistiram na sucessão de soja (verão) e pastagem mista de aveia-preta + azevém (inverno), com diferentes intensidades de pastejo por bovino de corte: pastejo intensivo, com altura de pastejo de $0,10 \mathrm{~m}$; pastejo moderado, com altura de pastejo de $0,20 \mathrm{~m}$; e sem pastejo. No ciclo da soja, na safra 2011/2012, a precipitação foi de 40\% da normal climatológica. A umidade do solo ficou dentro dos limites de água disponível, tanto em pastejo moderado quanto sem pastejo, na camada de $0,00-0,50 \mathrm{~m}$, mas, em pastejo intensivo, a umidade do solo foi menor que o ponto de murcha permanente, especialmente até $0,20 \mathrm{~m}$ de altura de pastejo. O pastejo intensivo afetou negativamente os parâmetros fisiológicos da soja, que atingiu picos de $-2.5 \mathrm{MPa} e+6^{\circ} \mathrm{C}$ para potencial de água na folha e diferença entre temperatura do ar e da folha, respectivamente. $\mathrm{O}$ pastejo moderado ou a ausência de pastejo, durante o inverno, acarreta respostas fisiológicas similares, o que contribui para a homeostase da soja.

Termos para indexação: Glycine max, temperatura da folha, potencial de água na folha, disponibilidade de água.

\section{Introduction}

Land use efficiency in tropical and subtropical areas, which in some periods of the year remain only with cover crops, may be increased by the adoption of integrated crop-livestock (ICL) systems. Including ruminant animals to explore the forage capacity of cover crops in ICL systems could provide higher flexibility

Pesq. agropec. bras., Brasília, v.51, n.8, p.978-989, ago. 2016

DOI: $10.1590 / \mathrm{S} 0100-204 X 2016000800010$ 
for producers (Sulc \& Tracy, 2007; Moraes et al., 2014) and also increase nutrient use efficiency (Costa et al., 2014; Martins et al., 2014b), soil biodiversity (Chávez et al., 2011) and economic performance (Oliveira et al., 2014). However, farmers resist adopting ICL systems, since they believe that grazing impacts negatively the cash crop development.

In areas where livestock needs to be integrated with crops, that is, where traditional grain cropping is adopted without livestock exploration (Anghinoni et al., 2013), the impacts of winter grazing on summer crop performance are not clearly established, especially for soybean. According to Martins et al. (2014a), the yield differences between areas with and without grazing occur mainly in summer seasons affected by drought, with rainfall above the climatological normal, when grazed areas result in lower yields. A plausible explanation for this behavior might be found in soil and plant water-related properties and in soybean physiology, since a poor crop establishment and a higher weed pressure were observed in areas where intensive grazing was performed before soybean sowing (Kunrath et al., 2015). However, due to the difficulty in measuring plant water status in the soil-plant-atmosphere continuum (Whitmore \& Whalley, 2009), this kind of approach is still scarce, particularly regarding ICL systems.

The use of plant physiological parameters, such as the difference between air and leaf temperatures, besides the leaf water potential $\left(\Psi_{\mathrm{LW}}\right)$, is important in assessing plant response under variable water conditions. Due to iso- and anisohydric water behavior - decreasing or constant water availability during the hottest hours of the day (Bergonci et al., 2000) -, leaf water potential should be evaluated at two periods: in the afternoon $\left(\Psi_{\mathrm{LWN}}\right)$ and before sunrise $\left(\Psi_{\mathrm{LWB}}\right)$. Leaf temperature is also a good indicator of the water status of plants, since it represents energy balance in plants and depends on the water vapor flow at the canopy-atmosphere interface (Zia-Khan et al., 2015). When leaf and air temperature are in equilibrium (equilibrium evaporation) (Jones, 2014), the leaf-air temperature difference $(\Delta \mathrm{T})$ may indicate plant water status (González-Dugo et al., 2006). In this sense, the relevant approaches for the study of water dynamics in food production systems should be transdisciplinary and integrate knowledge of crop physiology, agrometeorology, and soils (Pieruschka et al., 2010).
When monitoring soil moisture content, $\Delta \mathrm{T}$ and $\Psi_{\mathrm{LW}}$ together may be extremely useful in evaluating water stress, considering the changes in biochemical, physiological, and cell-membrane structure processes (Yordanov et al., 2000).

In this context, understanding how winter grazing and its intensity impact soybean physiological parameters and soil water availability, during a drought season, may help to perform modifications in the management of areas under ICL systems, avoiding lower grain yields in these systems when compared with pure agricultural systems.

The objective of this work was to evaluate the impact of grazing intensities after 11 years of an integrated crop-livestock system, under no-tillage, on soil moisture and soybean physiological parameters during a summer season affected by drought.

\section{Materials and Methods}

A long-term ICL system was conducted since 2001 at the Espinilho farm, belonging to Agropecuária Cerro Coroado, located in the municipality of São Miguel das Missões, in the state of Rio Grande do Sul, in the South region of Brazil (28 $57^{\circ} 23^{\prime \prime} \mathrm{S}$, $54^{\circ} 21^{\prime} 22^{\prime \prime} \mathrm{W}$, at an altitude of $465 \mathrm{~m}$ above sea level). The experimental area of approximately 22 ha is in the Brazilian subtropics, which has a warm, humid summer climate, $\mathrm{Cfa}$, according to the Köppen-Geiger classification. The average temperature is $19^{\circ} \mathrm{C}$, and yearly average rainfall is $1,850 \mathrm{~mm}$ (Matzenauer et al., 2013). The area is characterized by slopes of 0.02 to $0.10 \mathrm{~m} \mathrm{~m}^{-1}$, and the soil is classified as a Latossolo Vermelho distroferric, i.e., a Rhodic Hapludox (Soil Survey Staff, 1999), which is deep, well-drained, and dark-red, with a clayey texture $(540,270$, and $190 \mathrm{~g} \mathrm{~kg}^{-1}$ of clay, silt, and sand, respectively). Kaolinite and hematite are the predominant minerals in the clay fraction (Cecagno et al., 2016). Prior to the establishment of the experiment, the area had been managed under a no-tillage system since 1993. In November 2000, soil was sampled and analyzed for chemical characterization at the $0.00-0.05,0.05-0.10$, $0.10-0.15$, and $0.15-0.20-\mathrm{m}$ soil layers, according to Tedesco et al. (1995). The obtained values ranged from: 42 to $26 \mathrm{~g} \mathrm{~kg}^{-1}$ for soil organic matter; 4.9 to 4.6 for $\mathrm{pH}$; 13.4 to $3.7 \mathrm{mg} \mathrm{kg}^{-1}$ for available P; 240 to $55 \mathrm{mg} \mathrm{kg}^{-1}$ for available $\mathrm{K} ; 62$ to $40 \mathrm{mmol}_{\mathrm{c}} \mathrm{kg}^{-1}$ for exchangeable 
$\mathrm{Ca} ; 22$ to $11 \mathrm{mmol}_{\mathrm{c}} \mathrm{kg}^{-1}$ for exchangeable $\mathrm{Mg} ; 7$ to $1 \mathrm{mmol}_{\mathrm{c}} \mathrm{kg}^{-1}$ for exchangeable $\mathrm{Al} ; 48$ to $34 \%$ for base saturation; and 17 to $4 \%$ for aluminum saturation.

Grazing by beef cattle began in June 2001 in a pasture system with mixed species: 'Iapar 61' black oat (Avena strigosa Schreb.) + Italian ryegrass ("common" Lolium multiflorum Lam.). The soybean/beef cattle integration consisted of grazing cycles from May to November, in the winter season, and of soybean cropping [Glycine $\max (\mathrm{L}$.) Merr.] - with the cultivars Iguaçu in the first three seasons and Nidera RR in the remaining ones - from November to May, in the summer season. A total of $45 \mathrm{~kg} \mathrm{ha}^{-1}$ black oat was seeded each year, and Italian ryegrass was established by natural reseeding. At the end of the winter season, existing plant coverage was desiccated, and, in December of each year, soybean was seeded in rows spaced $0.45 \mathrm{~m}$ apart at a density of 45 seeds per square meter. Seed inoculation was performed as recommended for the crop, using Masterfix peat inoculant, whereas agronomic management (herbicide, insecticide, and fungicide use) was conducted according to technical recommendations. Soybean was harvested every March or April.

Treatments consisted of grazing intensities during winter, which were determined by the following grazing pasture heights, in a randomized complete block design, with three replicates: intensive grazing, with $0.10-\mathrm{m}$ pasture height; moderate grazing, with 0.20-m pasture height; and no grazing, as a reference treatment. The bovine stocking rates for intensive and moderate grazing treatments were $1,306 \pm 138$ and $931 \pm 84 \mathrm{~kg} \mathrm{ha}^{-1}$ of liveweight, representing an average of ten years, from 2001 to 2011 .

Neutered male steers (crossbred Angus, Hereford, and Nellore), approximately 12 months old and weighing about $200 \mathrm{~kg}$, began grazing in a cattle fattening or finishing system. During the grazing cycle, cattle feed was forage-based with mineral salt supply. A continuous grazing system was adopted with a minimum of three remaining steers (test steers), and grazing began when forage height reached approximately $0.25 \mathrm{~m}$. Therefore, each grazing cycle was carried out from the first half of July to the first half of November. Pasture height was controlled every 14 days by the sward-stick method. Approximately 100 randomized readings (points) were taken in each plot. Average pasture height resulted from managing grazing intensity (stocks) by adding or removing steers from each plot as required.

Plant and soil evaluations for the present study started after the 2011 grazing season, which began on $11 / 1 / 2011$ and went until soybean harvest on 3/31/2012, named 2011/2012 growing season. The soybean cultivar Nidera 6411 was seeded in November 16, with $0.45-\mathrm{m}$ row spacing and a seed density of 16 seeds per square meter. This cultivar is characterized by a determined growth cycle of 1,150-130 degree-days and belongs to the semi-early maturity group. Fertilization consisted of $240 \mathrm{~kg} \mathrm{ha}^{-1}$ of the formula N-P $\mathrm{O}_{5}-\mathrm{K}_{2} \mathrm{O} 0-25-25$ that was broadcast applied, according to soil analysis and to the recommendation of Tedesco et al. (2004) for $4 \mathrm{Mg} \mathrm{ha}^{-1}$ yield.

A Nexus wireless weather station model TFA 35.1075.1 (TFA Dostmann GmbH \& Co., Wertheim, Deutschland) was installed within the experimental area. The station provided data on rainfall events, air relative humidity, and air temperature. From these data, distribution of rainfall, air temperature, and air relative humidity throughout the soybean season and evaluation dates were obtained (Figures 1 and 2). Crop growth stages were determined from field observations, since the crop development cycle accelerated due to the low rainfall.

Disturbed soil samples were collected from 4:00 a.m. to 6:30 a.m., to obtain $\Psi_{\mathrm{LWB}}$ and leaf temperature before sunrise $\left(\mathrm{LT}_{\mathrm{B}}\right)$, and from 11:30 a.m. to 1:30 p.m., to determine $\Psi_{\mathrm{LWN}}$ and leaf temperature in the afternoon $\left(\mathrm{LT}_{\mathrm{N}}\right)$, at 24-26, 69-73, 82-86, and 117-119 days after sowing (DAS), which corresponds to the vegetative, blooming, bean-filling, and maturity stages, respectively. The evaluated soil layers were: $0.00-0.05,0.05-0.10,0.10-0.20,0.20-0.30$, and 0.30 $0.50 \mathrm{~m}$, in order to determine gravimetric moisture and, by correcting for soil bulk density, volumetric moisture $\left(\theta_{\mathrm{v}}\right)$. The limits of available water, namely field capacity $\left(\theta_{\mathrm{FC}}\right)$ and permanent wilting point $\left(\theta_{\mathrm{PWP}}\right)$, were used, according to Cecagno et al. (2016).

The leaf water potential $\left(\Psi_{\mathrm{LW}}\right)$ and leaf temperature of the soybean plants were assessed on the same periods of soil moisture stress. Five replicates (plants) were carried out for each treatment, and leaf temperature was obtained from the mean of three readings from the same plant. Plant leaf temperature was measured using an infrared thermometer with a thermal range from -10 to $60^{\circ} \mathrm{C}$, a standardized emissivity of 0.98 , 
and a $2.8^{\circ}$ field of view. Plant leaf temperature values were measured approximately at $0.15 \mathrm{~m}$ from the center of the adaxial leaf surface. Evaluations were only performed in leaves of the upper third part of the plants that received solar radiation, ensuring uniform measurements. This method is noninvasive and more appropriate for evaluating leaf temperature than the use of thermocouple sensors. Plant $\Psi_{\mathrm{LW}}$ was measured after obtaining leaf temperature in the field, using a Scholander pressure chamber to determine soil moisture. The $\Delta \mathrm{T}$ was calculated by subtracting air temperature from leaf temperature.

Due to the large plot size (1.8 ha in average), samplings were performed only in the first experimental block, since plant (leaf temperatures and leaf water potential) and soil (moisture monitoring) evaluations needed to be carried out simultaneously (Jones, 2014). Performing these assessments in the entire experimental area would lead to large, unacceptable time intervals between samplings and analyses. Since only one experimental block was evaluated, the results of the present study were analyzed as a completely randomized design, considering the sample units taken randomly within each treatment as replicates (pseudoreplicates) (Ferreira et al., 2012).
The results were subjected to analysis of variance and, when significant, means were compared by the t test, at 5\% probability. All statistical analyses were performed with the SAS software, version 9.4 (SAS Institute Inc., Cary, NC, USA), using the sources of variation "soil layer" or "sampling date" as a repeated measure over time (test with different covariance matrices, choosing the one with the lowest values for the Akaike information criterion and Bayesian information criterion), through the Proc Mixed procedure.

\section{Results and Discussion}

Soybean season was affected by severe drought (Figure 1), which greatly affected air relative humidity and temperature (Figure 2), as well as soil moisture (Figure 3). Since no differences were observed between available water, $\theta_{\mathrm{FC}}$, and $\theta_{\mathrm{PWP}}$, before sunrise and in the afternoon, the presented results are the average of both evaluation periods (Figure 3). Soil $\theta_{\mathrm{v}}$ increased with depth regardless of the treatment and remained within the available water range below $0.20-\mathrm{m}$ depth. In general, moderate grazing and no grazing conditions maintained $\theta_{\mathrm{v}}$ within the available water range in the entire soil profile measured at

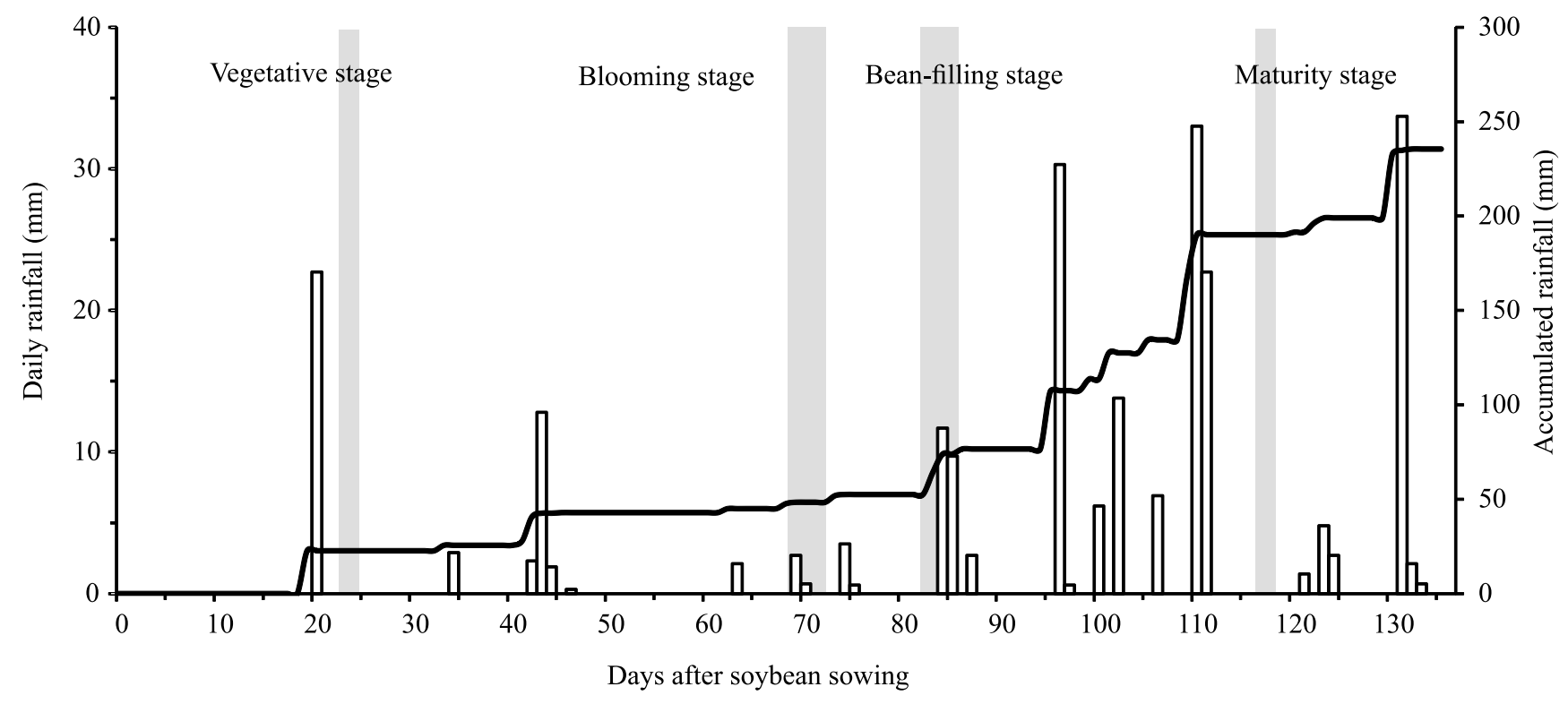

Figure 1. Daily (bars) and cumulative (continuous line) rainfall during the 2011/2012 soybean (Glycine max) crop season in a no-tillage, integrated crop-livestock (soybean and beef cattle) system in South Brazil. Rain accumulated in this period, according to the climatological normal, should be $680 \mathrm{~mm}$. Gray areas correspond to the evaluation periods of the physiological parameters of plants. 
$0.00-0.50 \mathrm{~m}$. However, independently of its intensity, grazing contributed less than no grazing in maintaining soil moisture content during the periods of critical demand by the crop, i.e., during the blooming and bean-filling stages. In addition, under grazing, lower moisture was observed in the top soil layer, whereas, under no grazing, there was higher moisture virtually everywhere. Under intensive grazing conditions, soil
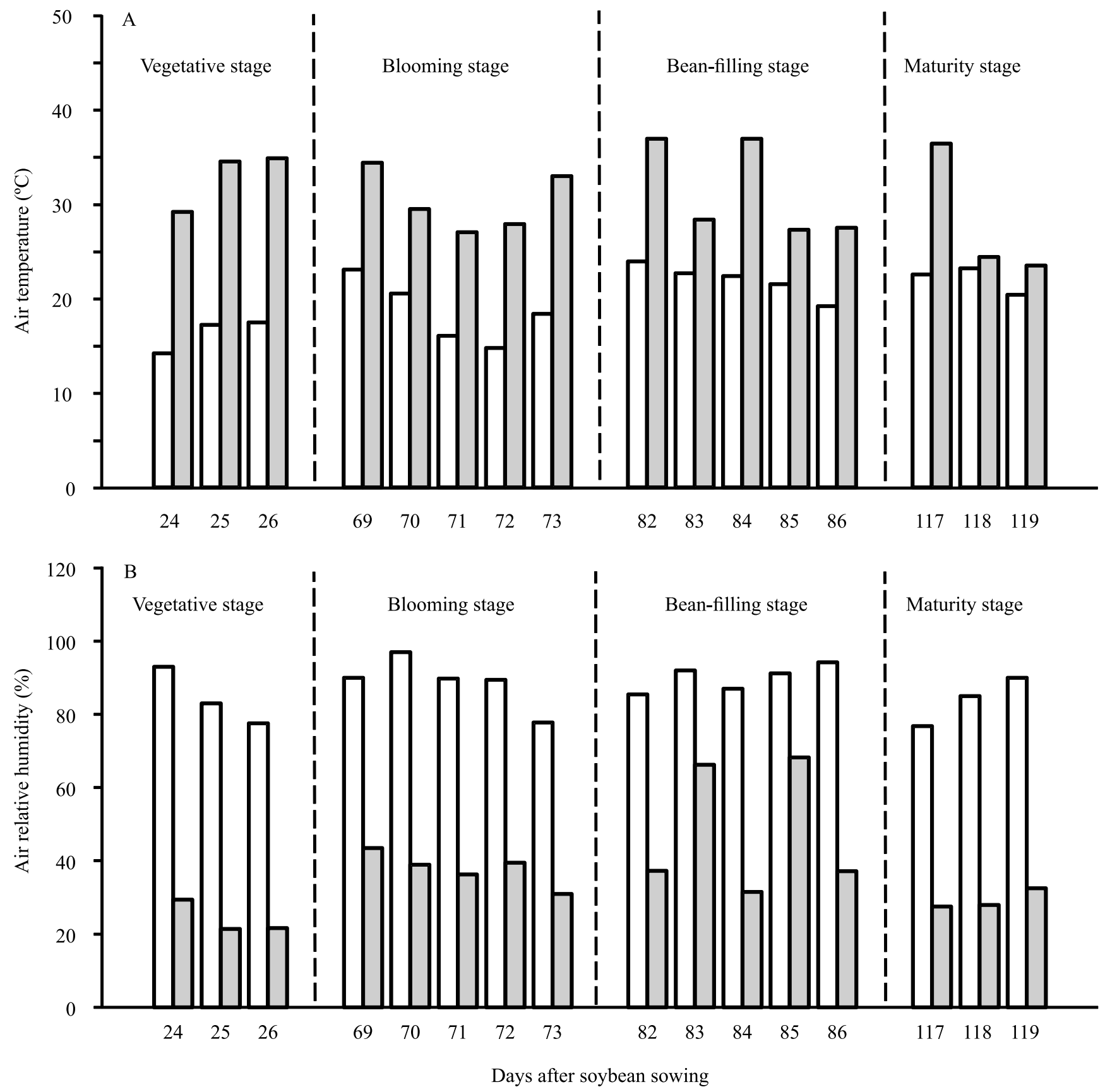

4:00 a.m. to 6:30 a.m. 口 11:30 a.m. to 1:30 p.m.

Figure 2. Air temperature (A) and air relative humidity (B) before sunrise (4:00 a.m. to 6:30 a.m.) and in the afternoon (from 11:30 a.m. to 1:30 p.m.) in different soybean (Glycine max) growth stages, in the 2011/2012 crop season, in a no-tillage, integrated crop-livestock (soybean and beef cattle) system in South Brazil. 
$\theta_{\mathrm{v}}$ remained below $\theta_{\mathrm{PWP}}$ at surface layers from sowing until the crop's blooming stage in January and again at soybean harvest. In the bean-filling stage, a period with higher rainfall intensity, there was increased $\theta_{\mathrm{v}}$ in the surface layers, that is, at $0.00-0.05$ and $0.05-0.10-\mathrm{m}$ depths. However, in the maturity stage, only no grazing showed moisture similar to that registered in the previous month.

Changes observed in the soil profile throughout the soybean cycle can be explained by the complexity in the soil water extraction process due to the simultaneous occurrence of water evaporation and redistribution processes in the soil, besides the effect of drying time. It is still unclear why there was greater soil surface moisture oscillation at $0.00-0.05$ and $0.05-0.10-\mathrm{m}$ depths, under grazing treatments, during the higher crop water demand months, i.e., the blooming and bean-filling stages (Figure 3). This can be attributed to the absence or inefficiency of the hydraulic redistribution process (capillary rise), which depends on which water potential there is a crossover of the unsaturated water conductivity curves to structured and more-compacted soil. Regarding intensive grazing conditions, the water loss is higher mainly on soil surface, due to the low amount of residues remaining from the grazing season, which results in increasing soil temperature and water evaporation. Quantity of forage offered also changes the soil water infiltration rate and water availability (Bertol et al., 2000). Furthermore, water availability at soybean sowing directly affects crop stand (Thomas \& Costa, 2010), increasing the need for efficient water cycling during the system's productive cycle. Lower soil moisture on the surface layer under intensive grazing conditions shows low water buffering of this management under the ICL system.

Despite the long-term benefits observed under moderate grazing in the ICL system (Moraes et al., 2014), the used succession (pasture-soybean) may minimize the benefits of partitioning water use (Mekonnen et al., 2011). Since the 2011/2012 soybean crop season developed under critical water stress conditions (Figure 1), the low water use in the soil profile is an indicator of the vulnerability of the ICL system with crop succession in rainfed systems, regardless of the adopted production system. From sowing to harvest, approximately $45 \%$ of soil water in the profile remained stored below $0.30-\mathrm{m}$ depth
(Figure 3). Most studies considering soil water distribution and physicochemical properties focus on soil surface layers, since most of the impacts of soil management affect these depths until $0.30 \mathrm{~m}$ (Gubiani et al., 2013).

The effects of the grazing intensities on soybean water status during crop development were observed regarding plant $\Psi_{\mathrm{LW}}$ values (Figure 4). Plant $\Psi_{\mathrm{LWB}}$ values ranged from 0 to $-1.3 \mathrm{MPa}$, whereas $\Psi_{\mathrm{LWN}}$ values ranged from -0.5 to $-2.5 \mathrm{MPa}$, being within the range obtained for soybean crop under water stress conditions in the field (Rawson et al., 1978). This range shows the indispensability of measurements before sunrise due to the anisotropic water behavior of the soybean crop (Bergonci et al., 2000). Therefore, the values for $\Psi_{\text {LWB }}$ were higher, whereas those for $\Psi_{\text {LWN }}$ were lower because of the accentuated decrease that occurs during the hottest hours of the day.

Under intensive grazing conditions, plant $\Psi_{\mathrm{LWN}}$ reached mean values of -1.6 and peaks of $-2.2 \mathrm{MPa}$ (Figure 4). In contrast, moderate grazing presented similar $\Psi_{\mathrm{LWB}}$ values to no grazing at the vegetative stage, from 24 to $26 \mathrm{DAS}$, despite the lower soil moisture. Before sunrise and stomatal opening, when plants tend to enter in equilibrium with soil, the behavior of $\Psi_{\mathrm{LWB}}$ at the blooming stage, from 69 to 73 DAS, was similar to that observed in the previously evaluated period, from 24 to $26 \mathrm{DAS}$, when intensive grazing areas exhibited higher degree of water stress in comparison with no grazing and moderate grazing. The same occurred during the plant water stress peak, in which the $\Psi_{\mathrm{LW}}$ behavior, at blooming, in the afternoon $\left(\Psi_{\mathrm{LWN}}\right)$ was similar to the one verified in the vegetative stage. Although there were alternating $\Psi_{\mathrm{LW}}$ values between no grazing and moderate grazing, both treatments, overall, showed higher values when compared with intensive grazing.

When soybeans were at the bean-filling stage, from 82 to $86 \mathrm{DAS}$, in general, treatments presented similar $\Psi_{\mathrm{LWB}}$ values (Figure 4). However, during the diurnal period of the critical crop stress, that is, in the afternoon, $\Psi_{\mathrm{LWN}}$ under no grazing was lower during some days, when compared with the two grazing treatments. These results are relevant, since, in this period, no grazing presented higher soil moisture and could be related to the depth of the root systems, which grow less in the earlier period of soybean development due to the higher moisture in soil surface layers in this 

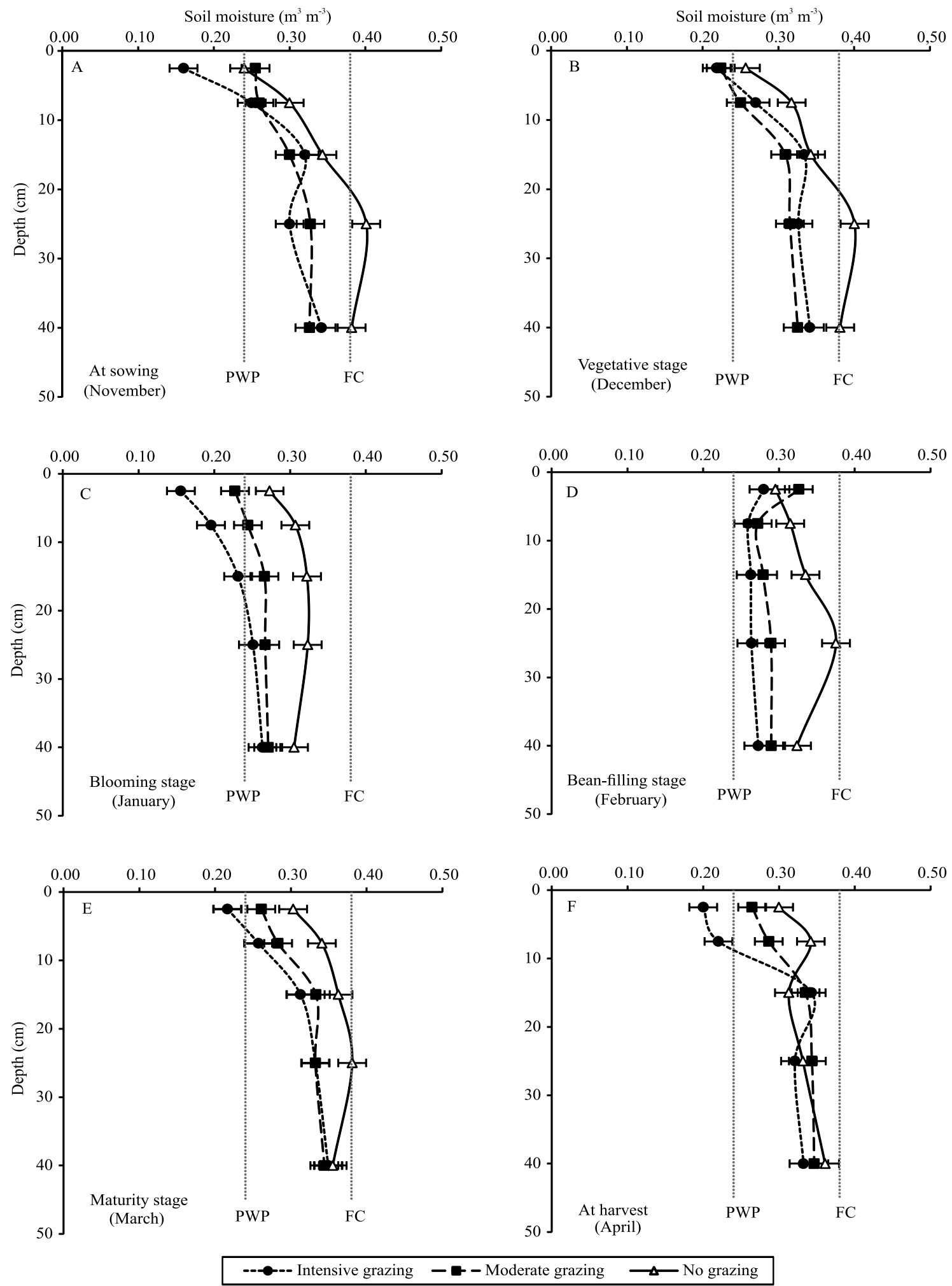

Figure 3. Soil volumetric moisture of a Latossolo Vermelho-Escuro argiloso (Rhodic Hapludox) at sowing (A), throughout different soybean (Glycine max) growth stages (B, vegetative; $\mathrm{C}$, blooming; $\mathrm{D}$, bean-filling; and $\mathrm{E}$, maturity), and at harvest (F), in a no-tillage, integrated crop-livestock (soybean and beef cattle) system under different grazing intensities in South Brazil. PWP, permanent wilting point; and FC, field capacity. Horizontal bars represent the least significant difference of the $\mathrm{t}$ test, at $5 \%$ probability. Intersecting bars represent no significant difference. 

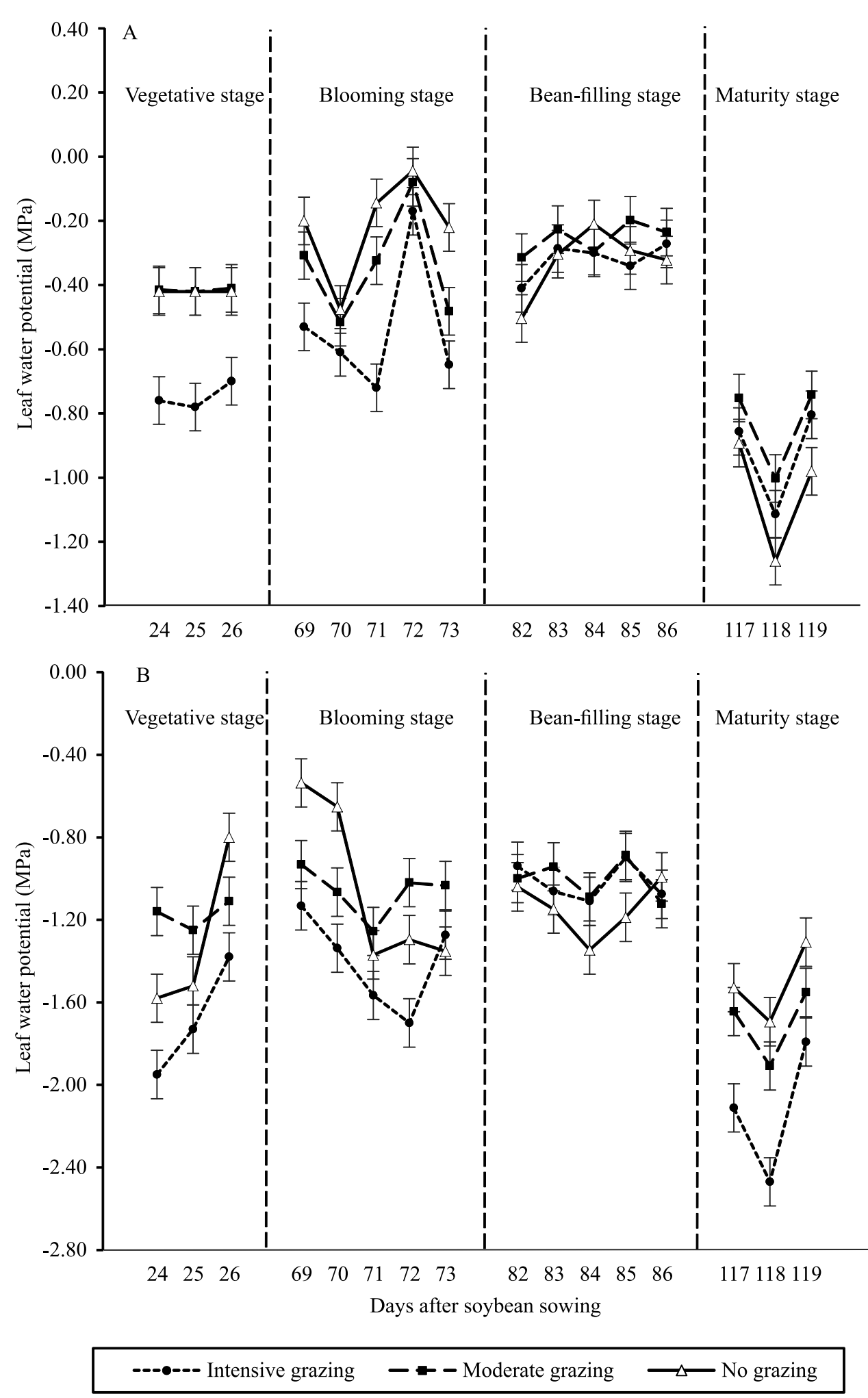

Figure 4. Soybean (Glycine max) leaf water potential before sunrise (A) and in the afternoon (B), in different growth stages, in a no-tillage, integrated crop-livestock (soybean and beef cattle) system under different grazing intensities in South Brazil. Vertical bars represent the least significant difference of the $t$ test, at $5 \%$ probability. Intersecting bars represent no significant difference. 
treatment. At the maturity stage, from 117 to 119 DAS, the same occurred for $\Psi_{\mathrm{LWB}}$, and the highest values were observed under moderate grazing. However, no grazing and moderate grazing presented higher values under afternoon stress conditions, whereas intensive grazing values were very low, oscillating from -2.0 to $-2.5 \mathrm{MPa}$.

The value of $\Psi_{\mathrm{LWN}}$ (Figure 4) under intensive grazing conditions has a key role, considering that, according to Oosterhuis et al. (1985), the leaf reorientation process in soybean plants starts from -1.4 MPa, representing the critical value for this cash crop. Even under equilibrium conditions $\left(\Psi_{\mathrm{LWB}}\right)$, values lower than $-0.4 \mathrm{MPa}$ were found. Such value is considered the threshold for the onset of leaf growth inhibition, even more important when compared with the negative effects on photosynthesis; moreover, values below -1.1 MPa result in a reduced soybean photosynthetic rate (Boyer, 1970). Rawson et al. (1978) pointed out that, during the soil drying process, soybean $\Psi_{\mathrm{LW}}$ can reach values below $-2.7 \mathrm{MPa}$, and reduced leaf conductivity and photosynthesis occur from values below $-1.5 \mathrm{MPa}$.

Otherwise, moderate grazing contributed to soybean water status in a positive manner, such that, in the vegetative stage, $\Psi_{\text {LWB }}$ values were similar to those observed for no grazing (Figure 4), despite the lower soil moisture (Figure 3). The many benefits in the soil-plant-atmosphere system promoted by adequate grazing, i.e., moderate grazing, according to Anghinoni et al. (2013), may explain the higher $\Psi_{\mathrm{LWN}}$ values in comparison with no grazing. This corroborates the results obtained by Moraes et al. (2014), who showed that the adequate management of ICL systems in the long term promotes improvements to the system as a whole, including the soil's capacity to promote adequate conditions for plant development even under abiotic stress, such as the drought that occurred in the evaluated season.

Leaf temperature is a representative physiological parameter of plant water status and its behavior in relation to air temperature is essential under a systemic analysis (Yu et al., 2015). The $\Delta \mathrm{T}$ values were consistent with the water stress conditions in which soybean developed (Figures 1 and 3): the lower the $\Delta \mathrm{T}$ value, the higher the degree of plant cooling and the lower the plant water stress (Figure 5). Overall, independently of the soil management system, negative $\Delta T_{B}$ values were observed, representing lower leaf temperature, when compared with that of air, and, consequently, lower water stress conditions. $\Delta \mathrm{T}_{\mathrm{B}}$ values ranged from -5.5 to $0.5^{\circ} \mathrm{C}$, and $\Delta \mathrm{T}_{\mathrm{N}}$ values, from -10 to $6^{\circ} \mathrm{C}$.

In the vegetative stage, in which measurements were performed from 24 to $26 \mathrm{DAS}, \mathrm{LT}_{\mathrm{B}}$ exhibited lower differences in comparison with air under intensive grazing, followed by moderate and no grazing (Figure 5). The same conditions were observed for $\Delta \mathrm{T}_{\mathrm{N}}$; however, moderate grazing showed lower values than no grazing. The $\Delta \mathrm{T}_{\mathrm{B}}$ behavior during the blooming stage, from 69 to $73 \mathrm{DAS}$, was similar to that observed in the vegetative stage, with lower values for no grazing, followed by moderate and intensive grazing. In contrast, except for the first day of evaluation, grazing systems showed lower $\Delta \mathrm{T}_{\mathrm{N}}$ in this month, in comparison with no grazing.

At the bean-filling stage, from 82 to 86 DAS, $\Delta \mathrm{T}$ values presented higher range, from 6 to $-4^{\circ} \mathrm{C}$ (Figure 5), regardless of the adopted management system. However, a change in the effect of management systems in $\Delta \mathrm{T}_{\mathrm{B}}$ was observed, with high variations among treatments and evaluation days. Despite the lack of rainfall during the soybean cycle (Figure 1), rainfall was higher in the current period than in the other ones, with 75 of the total $235 \mathrm{~mm}(32 \%)$. Rainfall before the experimental period alters the magnitude of soybean response to soil water and atmospheric conditions. During the first two days, grazing systems showed lower $\Delta T_{B}$ values, whereas an inverse behavior was verified during the following days, with grazing systems reaching the highest values. At the end of this evaluation period, at 86 DAS, no differences were observed among treatments. Despite these results, all management systems had $\Delta \mathrm{T}_{\mathrm{N}}>-10^{\circ} \mathrm{C}$ between January and February, i.e., the flowering and bean-filling stages. Comparing $\Delta \mathrm{T}_{\mathrm{N}}$ in February, the values were higher under intensive grazing than under moderate and no grazing.

At the maturity stage, from 117 to 119 DAS, the last assessed period, moderate grazing exhibited lower $\Delta \mathrm{T}_{\mathrm{B}}$ values than no grazing, which, in turn, on the last evaluation day, presented higher values than the intensive and moderate grazing systems (Figure 5). A similar behavior was found for $\Psi_{\mathrm{LWB}}$ in the same month (Figure 4). In contrast, soybean showed higher stress under the intensive grazing system, with higher $\Delta \mathrm{T}_{\mathrm{N}}$ when compared with moderate and no grazing. 
Overall, positive $\Delta T_{N}$ values were found for grazing conditions, despite grazing intensity, whereas no grazing resulted in negative values. Crop conditions are better characterized by $\Delta \mathrm{T}$ than by soil moisture (Yu et al., 2015). When soybean plants had grains close to maturation and during harvest, from 117 to
119 DAS, intensive grazing still contributed to high $\Delta \mathrm{T}_{\mathrm{N}}$ values, following the trend observed throughout the soybean cycle. This result shows how water stress is a cumulative process. Positive values were verified in no grazing, indicating that this is a more efficient system regarding soybean homeostasis.
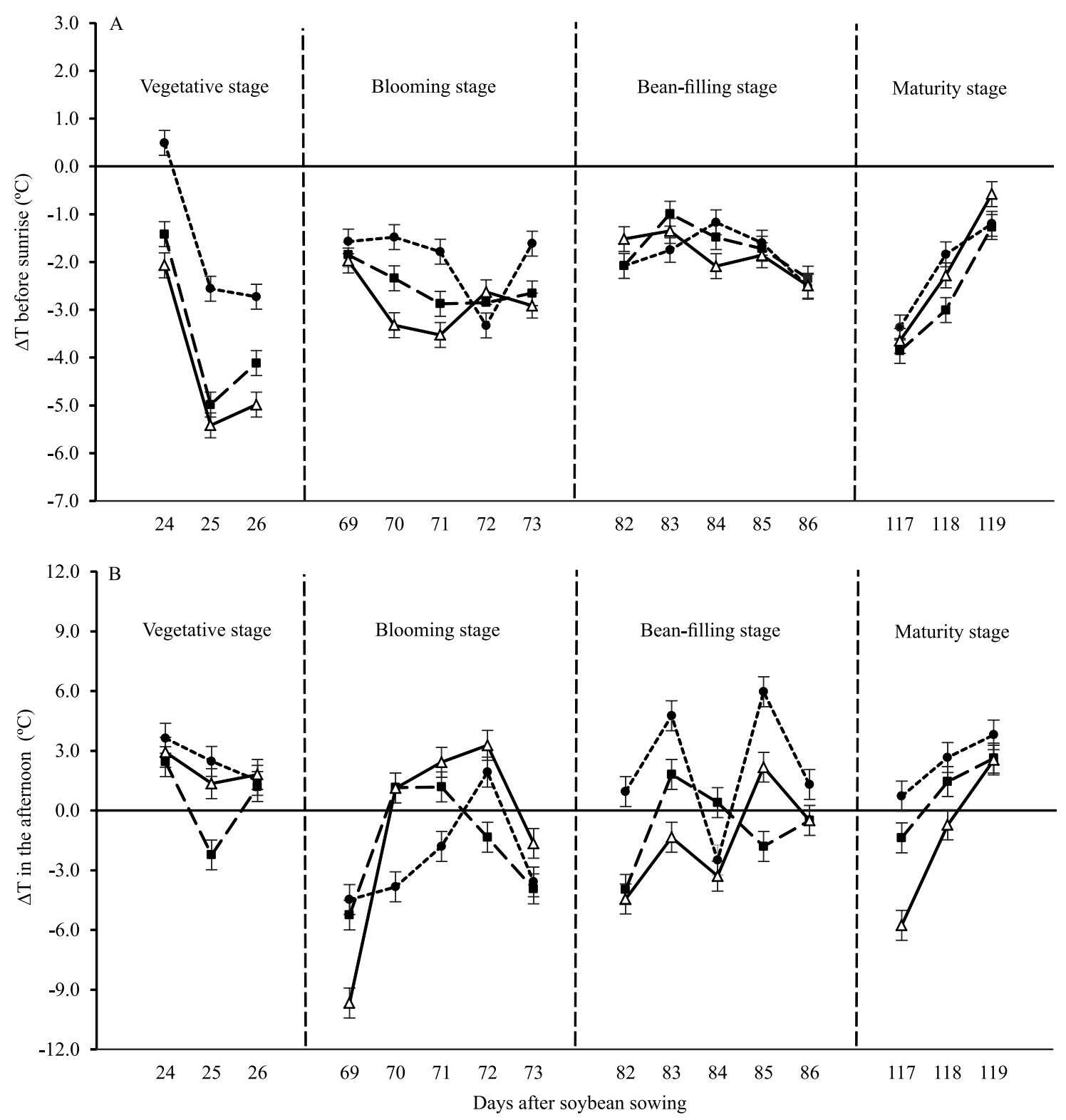

---๑-- Intensive grazing $\quad-\bullet-$ Moderate grazing $\quad \longrightarrow$ No grazing

Figure 5. Difference between soybean (Glycine max) leaf and air temperature $(\Delta \mathrm{T})$ before sunrise $(\mathrm{A})$ and in the afternoon (B), in different growth stages, in a no-tillage, integrated crop-livestock (soybean and beef cattle) system under different grazing intensities in South Brazil. Vertical bars represent the least significant difference of the $t$ test, at $5 \%$ probability. Intersecting bars represent no significant difference. 
The dynamics of soybean water status, resulting from crop development under open-system conditions, demands a complex understanding, suggesting the need for separating individual (plant) from canopy (crop) behavior in further studies. In these studies, deep soil layers, above $0.30 \mathrm{~m}$, must be considered, because, as shown, much of the soil moisture content under drought events is maintained in these layers, which could contribute to the water rise process.

\section{Conclusions}

1. In a summer season affected by drought, the crop-livestock system under intensive winter grazing, with pasture height up to $0.20 \mathrm{~m}$, results in lower soil moisture, when compared with no grazing areas.

2. Soybean (Glycine max) physiological parameters, i.e., leaf water potential and leaf temperature, are severely and negatively affected by intensive grazing.

3. Moderate grazing or the absence of grazing during the winter season results in similar physiological responses in soybean, contributing to plant homeostasis.

\section{Acknowledgments}

To Coordenação de Aperfeiçoamento de Pessoal de Nível Superior (Capes) and to Conselho Nacional de Desenvolvimento Científico e Tecnológico (CNPq, project No. 479877/2011-4), for scholarship grant and financial support; to Adão Luis Ramos dos Santos, for the support provided in laboratorial analyses and in field activities; and to Cabanha Cerro Coroado, for providing the experimental area, animals, machinery, and field support.

\section{References}

ANGHINONI, I.; CARVALHO, P.C. de F.; COSTA, S.E.V.G. de A. Abordagem sistêmica do solo em sistemas integrados de produção agrícola e pecuária no subtrópico brasileiro. Tópicos em Ciência do Solo, v.8, p.325-380, 2013.

BERGONCI, J.I.; BERGAMASCHI, H.; BERLATO, M.A.; SANTOS, A.O. Potencial da água na folha como um indicador de déficit hídrico em milho. Pesquisa Agropecuária Brasileira, v.35, p.1531-1540, 2000. DOI: 10.1590/S0100-204X2000000800005.

BERTOL, I.; ALMEIDA, J.A. de; ALMEIDA, E.X. de; KURTZ, C. Propriedades físicas do solo relacionadas a diferentes níveis de oferta de forragem de capim-elefante-anão cv. Mott. Pesquisa Agropecuária Brasileira, v.35, p.1047-1054, 2000. DOI: 10.1590/ S0100-204X2000000500024.
BOYER, J.S. Leaf enlargement and metabolic rates in corn, soybean, and sunflower at various leaf water potentials. Plant Physiology, v.46, p.233-235, 1970. DOI: 10.1104/pp.46.2.233.

CECAGNO, D.; COSTA, S.E.V.G. de A.; ANGHINONI, I.; KUNRATH, T.R.; MARTINS, A.P.; REICHERT, J.M.; GUBIANI, P.I.; BALERINI, F.; FINK, J.R.; CARVALHO, P.C. de F. Least limiting water range and soybean yield in a long-term, no-till, integrated crop-livestock system under different grazing intensities. Soil and Tillage Research, v.156, p.54-62, 2016. DOI: 10.1016/j. still.2015.10.005.

CHÁVEZ, L.F.; ESCOBAR, L.F.; ANGHINONI, I.; CARVALHO, P.C. de F.; MEURER, E.J. Diversidade metabólica e atividade microbiana no solo em sistema de integração lavoura-pecuária sob intensidades de pastejo. Pesquisa Agropecuária Brasileira, v.46, p.1254-1261, 2011. DOI: 10.1590/S0100-204X2011001000020.

COSTA, S.E.V.G.A.; SOUZA, E.D.; ANGHINONI, I.; CARVALHO, P.C.F.; MARTINS, A.P.; KUNRATH, T.R.; CECAGNO, D.; BALERINI, F. Impact of an integrated no-till crop-livestock system on phosphorus distribution, availability and stock. Agriculture, Ecosystems and Environment, v.190, p. 43-51, 2014.

FERREIRA, D.F.; FILHO, A.C.; LÚCIO, A.D. Procedimentos estatísticos em planejamentos experimentais com restrição na casualização. Boletim Informativo da Sociedade Brasileira de Ciência do Solo, v.37, p.16-19, 2012.

GONZÁLEZ-DUGO, M.P.; MORAN, M.S.; MATEOS, L.; BRYANT, R. Canopy temperature variability as an indicator of crop water stress severity. Irrigation Science, v.24, p.233-240, 2006. DOI: $10.1007 / \mathrm{s} 00271-005-0022-8$.

GUBIANI, P.I.; REICHERT, J.M.; REINERT, D.J. Indicadores hídrico-mecânicos de compactação do solo e crescimento de plantas. Revista Brasileira de Ciência do Solo, v.37, p.1-10, 2013. DOI: $10.1590 / \mathrm{S} 0100-06832013000100001$.

JONES, H.G. Plants and microclimate: a quantitative approach to environmental plant physiology. $3^{\text {rd }}$ ed. Cambridge: Cambridge University Press, 2014. 423p.

KUNRATH, T.R.; CARVALHO, P.C. de F.; CADENAZZI, M.; BREDEMEIER, C.; ANGHINONI, I. Grazing management in an integrated crop-livestock system: soybean development and grain yield. Revista Ciência Agronômica, v.46, p.645-653, 2015. DOI: 10.5935/1806-6690.20150049.

MARTINS, A.P.; ANGHINONI, I.; COSTA, S.E.V.G. de A.; CARLOS, F.S.; NICHEL, G. de H.; SILVA, R.A.P.; CARVALHO, P.C. de F. Amelioration of soil acidity and soybean yield after surface lime reapplication to a long-term no-till integrated crop-livestock system under varying grazing intensities. Soil and Tillage Research, v.144, p.141-149, 2014a. DOI: 10.1016/j. still.2014.07.019

MARTINS, A.P.; COSTA, S.E.V.G. de A.; ANGHINONI, I.; KUNRATH, T.R.; BALERINI, F.; CECAGNO, D.; CARVALHO, P.C. de F. Soil acidification and basic cation use efficiency in an integrated no-till crop-livestock system under different grazing intensities. Agriculture, Ecosystems and Environment, v.195, p.18-28, 2014b. DOI: 10.1016/j.agee.2014.05.012. 
MATZENAUER, R.; RADIN, B.; ALMEIDA, I.R. de (Ed.). Atlas climático do Rio Grande do Sul. [Porto Alegre]: CEMETRS, 2013. Available at: <http://www.r3pb.com.br/AtlasCemetRS $>$. Accessed on: May 272013.

MEKONNEN, S.; DESCHEEMAEKER, K.; TOLERA, A.; AMEDE, T. Livestock water productivity in a water stressed environment in northern Ethiopia. Experimental Agriculture, v.47, p.85-98, 2011. Supplement 1. DOI: 10.1017/S0014479710000852.

MORAES, A. de; CARVALHO, P.C. de F.; ANGHINONI, I.; LUSTOSA, S.B.C.; COSTA, S.E.V.G. de A.; KUNRATH, T.R. Integrated crop-livestock systems in the Brazilian subtropics. European Journal of Agronomy, v.57, p.4-9, 2014. DOI: 10.1016/j.eja.2013.10.004.

OLIVEIRA, C.A.O. de; BREMM, C.; ANGHINONI, I.; MORAES, A. de; KUNRATH, T.R.; CARVALHO, P.C. de F. Comparison of an integrated crop-livestock system with soybean only: economic and production responses in southern Brazil. Renewable Agriculture and Food Systems, v.29, p.230-238, 2014. DOI: 10.1017/ S1742170513000410.

OOSTERHUIS, D.M.; WALKER, S.; EASTHAM, J. Soybean leaflet movements as an indicator of crop water stress. Crop Science, v.25, p.1101-1106, 1985. DOI: 10.2135/ cropsci1985.0011183X002500060048x.

PIERUSCHKA, R.; HUBER, G.; BERRY, J.A. Control of transpiration by radiation. Proceedings of the National Academy of Sciences, v.107, p.13372-13377, 2010. DOI: 10.1073/ pnas.0913177107.

RAWSON, H.M.; TURNER, N.C.; BEGG, J.E. Agronomic and physiological responses of soybean and sorghum crops to water deficits. IV. Photosynthesis, transpiration and water use efficiency in leaves. Australian Journal of Plant Physiology, v.5, p.195-209, 1978. DOI: 10.1071/PP9780195.
SOIL SURVEY STAFF. Soil taxonomy: a basic system of soil classification for making and interpreting soil surveys. $2^{\text {nd }}$ ed. Washington: USDA, 1999. (Agriculture Handbook $n^{\circ} 436$ ).

SULC, R.M.; TRACY, B.F. Integrated crop-livestock systems in the U.S. corn belt. Agronomy Journal, v.99, p.335-345, 2007. DOI: 10.2134 /agronj2006.0086.

TEDESCO, M.J.; GIANELLO, C.; BISSANI, C.A.A.; BOHNEN, H.; VOLKWEISS, S.J. Análises de solo, plantas e outros materiais. 2.ed. rev. e ampl. Porto Alegre: UFRGS, Departamento de Solos, 1995. 174p. (UFGRS. Boletim técnico, 5).

TEDESCO, M.J.; GIANELLO, C.; ANGHINONI, I.; BISSANI, C.A.; CAMARGO, F.A.O.; WIETHÖLTER, S. (Ed.). Manual de adubação e de calagem para os estados do Rio Grande do Sul e Santa Catarina. Porto Alegre: Sociedade Brasileira de Ciência do Solo, Núcleo Regional Sul, 2004. 400p.

THOMAS, A.L.; COSTA, J.A. (Org.). Soja: manejo para alta produtividade de grãos. Porto Alegre: Evangraf, 2010. 248p.

WHITMORE, A.P.; WHALLEY, W.R. Physical effects of soil drying on roots and crop growth. Journal of Experimental Botany, v.60, p.2845-2857, 2009. DOI: 10.1093/jxb/erp200.

YORDANOV, I.; VELIKOVA, V.; TSONEV, T. Plant responses to drought, acclimation, and stress tolerance. Photosynthetica, v.38, p.171-186, 2000. DOI: 10.1023/A:1007201411474.

YU, M.-H.; DING, G.-D.; GAO, G.-L.; SUN, B.-P.; ZHAO, Y.-Y.; WAN, L.; WANG, D.-Y.; GUI, Z.-Y. How the plant temperature links to the air temperature in the desert plant Artemisia ordosica. PLoS One, v.10, p.1-14, 2015. DOI: 10.1371/journal. pone.0135452.

ZIA-KHAN, S.; SPREER, W.; PENGNIAN, Y.; ZHAO, X.; OTHMANLI, H.; HE, X.; MÜLLER, J. Effect of dust deposition on stomatal conductance and leaf temperature of cotton in Northwest China. Water, v.7, p.116-131, 2015. DOI: 10.3390/w7010116.

Received on Octuber 23, 2015 and accepted on May 27, 2016

Pesq. agropec. bras., Brasília, v.51, n.8, p.978-989, ago. 2016 DOI: 10.1590/S0100-204X2016000800010 